\title{
Geographical structure of gene diversity in Quercus petraea (Matt.) Liebl. I. Monolocus patterns of variation
}

\author{
A. ZANETTO \& A. KREMER* \\ INRA, Laboratoire de Génétique et d'Amélioration des Arbres Forestiers, BP 45, 33611 Gazinet Cedex, France
}

\begin{abstract}
A gene diversity survey was conducted on a range-wide sample of 81 populations of Quercus petraea. Allele frequencies were calculated at 13 enzyme-coding loci, of which 11 were polymorphic. There was a clear discrepancy in the levels of diversity at loci controlling enzymes of primary metabolism compared with those involved in secondary metabolism, the latter being more variable than the former. Quercus petraea is a highly variable species as are other longlived widespread forest species: at the species level, the mean number of alleles per population was 4.77 and the expected heterozygosity 0.265 . Populations from the central part of the natural range exhibited fewer alleles but higher heterozygosities than populations from the margins of the distribution. Significant correlations were observed between allele frequencies and longitude for most loci, resulting in a clinal variation of allele frequencies across a continental gradient. The patterns of geographical variation in allele frequencies and levels of diversity were interpreted as a consequence of postglacial migration pathways.
\end{abstract}

Keywords: allozyme, diversity, genetic differentiation, heterozygosity, Quercus petraea, spatial autocorrelation.

\section{Introduction}

Geographical variation in forest trees has been widely studied in provenance research for morphological traits (Wright, 1976). For widespread species distributed over large latitudinal or continental ranges, clear geographical clinal trends of variation have usually been found and important population differences have been observed that were attributed to environmental selection pressures. On the other hand, allozyme population surveys in widespread forest species have resulted in extremely low population differentiation (Hamrick et al., 1992; Kremer, 1994), although geographical patterns have been detected (Lagercrantz \& Ryman, 1990) when rangewide studies were conducted. In contrast to phenotypic traits, geographical trends of variation in allozyme frequencies have been attributed to evolutionary footprints (Strauss et al., 1992), particularly recolonization routes.

Quercus petraea is a widespread species covering most of Europe from Spain to Russia and from Scotland to Turkey (Kleinschmit, 1993). Its natural

\footnotetext{
${ }^{*}$ Correspondence.
}

range is a continuous distribution, except in the southern limits where stands are scattered. Throughout its distribution, $Q$. petraea is associated with $Q$. robur resulting in mixed stands where unidirectional hybridization may occur, $Q$. petraea preferentially pollinating $Q$. robur (Bacilieri et al., 1995). Provenance tests based on regional population collections have been established in several European countries (see Kremer et al., 1993 for a review). While important population differences were discernible for growth and adaptive traits, no clear geographical trends appeared as a result of the limited regional population sampling.

Allozyme diversity studies in oaks (Kremer \& Petit, 1993) have shown similar patterns of variation to those of other forest tree species (Hamrick et al., 1992). A series of papers (Kremer et al., 1991; Müller-Starck \& Ziehe, 1991; Müller-Starck et al., 1993 ) has shown that $Q$. petraea is characterized by high within-population diversity associated with a low differentiation among populations. These studies, however, failed to reveal any geographical pattern in gene frequencies, mostly because they were limited to a regional population sample. It was our objective to address the geographical organiza- 
tion of allozyme diversity over the entire range of $Q$. petraea. Despite its large distribution, early results indicated only minor differentiation among populations (Zanetto et al., 1993). Our focus was to assess the geographical delineation of gene frequency and diversity differences, even if they were small. The population sampling strategy was therefore designed so that: (i) minor gene frequency variation could be detected, and (ii) the geographical distribution of gene frequency and gene diversity could be tested. The strategy consisted of sampling a large number of populations over the whole distribution of the species and of clustering populations in geographical groups so that comparisons could be made between groups. We attempted also to compare the geographical pattern of gene diversity with evolutionary records of postglacial migrations based on palynological data.

The second objective of this population study was to compare the levels of within-population diversity among populations. The underlying aim was to provide basic information for conservation strategies. Is the diversity evenly distributed throughout the natural range? Again the sampling strategy was designed so that various parameters of diversity could be accurately estimated. Particular attention was given to the number of alleles (allelic richness), a parameter that is more sensitive to frequency profiles than heterozygosity. As allozyme frequency profiles in forest trees are generally characterized by one rather frequent allele and several rare alleles (Conkle, 1992), a large sample size is required to estimate allelic richness.

\section{Materials and methods}

\section{Plant material}

Eighty-one populations of $Q$. petraea of putative native origin were sampled over the natural range of the species from Ireland to Turkey and from the Pyrenées to Norway. The sample also comprised populations originating from various altitudes ranging from sea level (French Brittany) to $1300 \mathrm{~m}$

Fig. 1 Geographical distribution of the populations of Quercus petraea. Populations were clustered in 14 groups according to their geographical proximities. 
(Alps), although most of the populations came from altitudes between 100 and $450 \mathrm{~m}$ (Fig. 1); only six populations originated from altitudes higher than $450 \mathrm{~m}$. Geographical data were recorded for each population (latitude, longitude, altitude) and are given elsewhere (Zanetto, 1995, unpublished Thesis). The populations were clustered in 14 groups according to their geographical proximity (Fig. 1). Several geographical clusterings of populations were tested according to proximity. The results of gene diversity and differentiation were very similar. The final choice resulted from a compromise between constant number of populations per group and geographical proximity.

In each stand, where a population was sampled, acorns were collected from the ground over an area of 15-20 ha, representing about 50 collecting points equally distributed with 100-200 seeds for each point. Seeds were only harvested when the fruiting was above average (more than 50 per cent of the trees bearing acorns). Seeds of all collection points were bulked in a single lot. A random sample of 120 seeds for each population was taken for the study of allozyme variation. In a few cases when collections could be made from single trees, open-pollinated progenies were collected in a stand from the same area. Acorns were harvested from at least 10 trees per stand ( 20 acorns for each family) and a random subset of 4-12 seeds per family was subsequently used for electrophoresis.

\section{Starch gel electrophoresis}

Acorns were soaked in water for $24 \mathrm{~h}$ and germinated on vermiculite in an incubator. When the radicles were $2-4 \mathrm{~cm}$ long, enzymes were extracted from the radicle tissues and separated by standard horizontal starch gel electrophoresis. Formulations for extraction, electrode and gel buffers are given in Zanetto et al. (1994). Buffer formulations for enzyme stains were adapted from Cheliak et al. (1984), Conkle et al. (1982) and Vallejos (1983).

Eleven enzymes were analysed for the population survey: acid phosphatase (ACP, EC 3.1.3.2), alanine aminopeptidase (AAP, EC 3.4.11.1), diaphorase (DIA, EC 1.8.1.4), glutamate oxaloacetate transaminase (GOT, EC 2.6.1.1), isocitrate dehydrogenase (IDH, EC 1.1.1.42), leucine aminopeptidase (LAP, EC 3.4.11.1), menadione reductase (MR, EC 1.6.99.2), malate dehydrogenase (MDH, EC 1.1.1.37), phosphoglucose isomerase (PGI, EC 5.3.1.9), phosphoglucomutase (PGM, EC 5.4.2.2), 6-phosphogluconate dehydrogenase (6PGD, EC 1.1.1.44). Segregation analysis (A. Zanetto et al.,

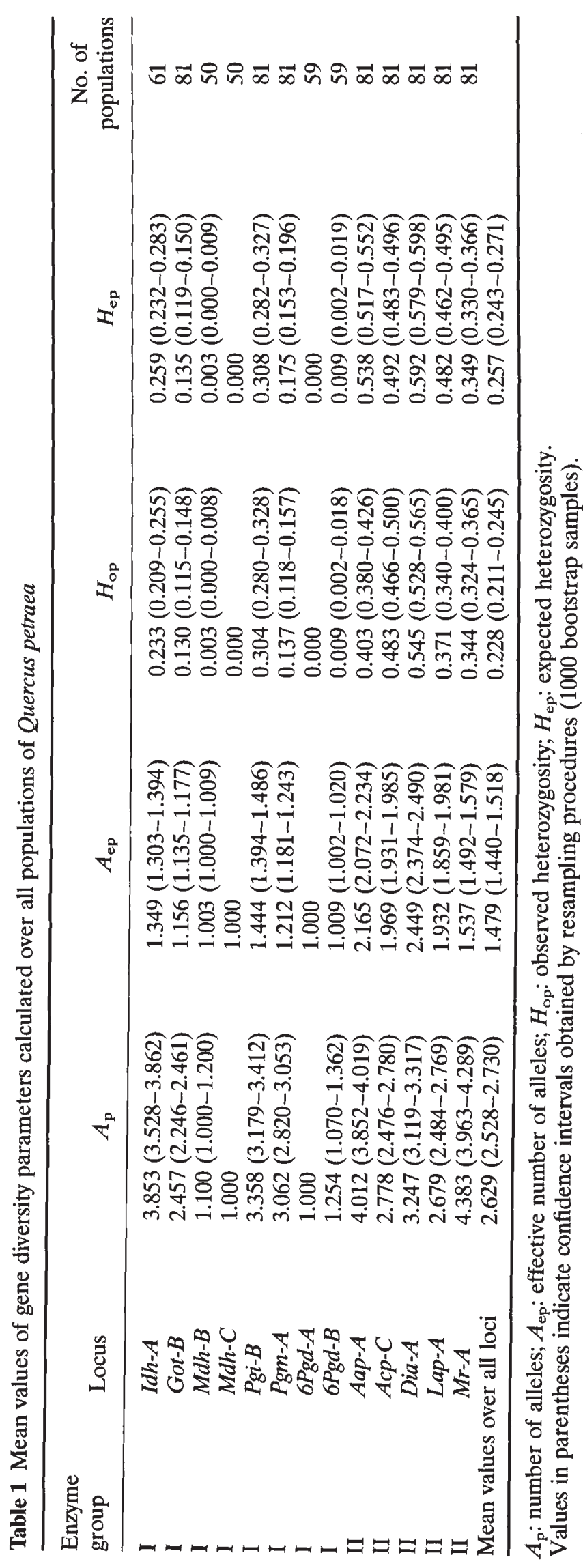

(C) The Genetical Society of Great Britain, Heredity, 75, 506-517. 
unpublished data) showed that these enzymes were encoded by 13 loci (Acp-C, Aap-A, Dia-A, Got-B, Idh-A, Lap-A, Mr-A, Mdh-B, Mdh-C, Pgi-B, Pgm-A, 6 Pgd-A, $6 P g d-B)$. Because of the continuous improvement of the methods during the experiment, the number of loci increased during the experiment from eight to 13 (see Table 1). As a consequence, only 50 populations could be analysed with 13 loci, and the total set (81 populations) with eight loci. The 13 enzymes can be separated into two different classes, according to the metabolism in which they are involved (Bergmann, 1991; enzymes of primary metabolism: class I; enzymes of secondary metabolism: class II; Table 1).

\section{Gene diversity and differentiation statistics}

Allele frequencies were calculated for each population and gene diversity parameters estimated on a within-population basis. The parameters were: the number of alleles per locus $\left(A_{\mathrm{p}}\right)$, the observed heterozygosity $\left(H_{\mathrm{op}}\right)$, the expected heterozygosity $\left(H_{\mathrm{ep}}\right)$ and the effective number of alleles $\left(A_{\mathrm{ep}}\right) . A_{\mathrm{p}}$ was counted within each population, $H_{\mathrm{op}}$ and $H_{\mathrm{ep}}$ calculated according to Brown \& Weir (1983) and $A_{\text {ep }}$ computed as $1 /\left(1-H_{\mathrm{ep}}\right)$. Confidence intervals for the mean value of each parameter (for each locus) were calculated empirically by a hierarchical bootstrapping over populations and individuals. One thousand bootstrap samples were generated for each sample.

Gene differentiation parameters were calculated with Nei's genetic diversity statistics (Nei, 1973, 1977; Nei \& Chesser, 1983). The total gene diversity $\left(H_{\mathrm{t}}\right)$ was subdivided into three components $\left(H_{\mathrm{s}}, D_{\mathrm{sg}}\right.$ and $\left.D_{\mathrm{gt}} ; H_{\mathrm{t}}=H_{\mathrm{s}}+D_{\mathrm{sg}}+D_{\mathrm{gt}}\right)$, where $H_{\mathrm{s}}$ was the within-population gene diversity, $D_{\mathrm{sg}}$ the component of diversity resulting from population subdivision and $D_{\mathrm{gt}}$ the component of diversity resulting from geographical group subdivision.

Levels of differentiation $\left[G_{\mathrm{st}}=\left(H_{t}-H_{\mathrm{s}}\right) / H_{\mathrm{t}}\right]$ within geographical groups were calculated by computing separately $H_{\mathrm{t}}$ and $H_{\mathrm{s}}$ within each group. As the coefficient $G_{\text {st }}$ also comprises differentiation within a population itself, $G_{\text {st }}$ values may only be compared between groups if the number of populations per group is constant. To avoid bias from the uneven numbers of populations sampled per group, absolute differentiation $\left(D_{m}\right)$ was calculated (Nei, 1977):

$D_{\mathrm{m}}=\frac{s}{s-1}\left(H_{\mathrm{t}}-H_{\mathrm{s}}\right)$,

where $s$ is the number of populations per group and $H_{\mathrm{t}}$ and $H_{\mathrm{s}}$ are, respectively, the total and the within- population gene diversities. The coefficient of absolute gene differentiation $\mathrm{G}^{\prime}{ }_{\mathrm{st}}$ is then:

$$
G_{s t}^{\prime}=\frac{D_{\mathrm{m}}}{H_{\mathrm{t}}+D_{\mathrm{m}}} \text {. }
$$

\section{Geographical variation of gene diversity and allele frequencies}

Geographical variation of gene diversity and allele frequencies was tested in two ways: (i) overall geographical differences were evaluated by one-way analysis of variance of data corresponding to the different geographical groups (Fig. 1); and (ii) product-moment correlation coefficients (Sokal \& Rohlf, 1981) were calculated between gene diversity statistics, allele frequencies and geographical data (latitude, longitude, altitude) to identify geographical trends of variation.

\section{Spatial analysis of allele frequencies}

Moran's I coefficients (Sokal et al., 1989) were calculated on the basis of allele frequencies. For each locus, only the most frequent allele was used for the autocorrelation analysis because allele frequencies for a given locus are not independent.

\section{Results}

\section{Variation of allele frequency profiles}

Allele frequency profiles differed markedly among the different enzymes. Frequency profiles referred to the distribution of allele frequencies for a given locus. The type of profile could be indicated by the discrepancy between values of $A_{\mathrm{p}}$ and $A_{\mathrm{ep}}$, the real and effective numbers of alleles. For example, if $A_{\mathrm{ep}}$ was close to 1 , and $A_{\mathrm{p}}$ was high ( $>3$ ), the frequency profile was characterized by a single most frequent allele (frequency $>0.9$ ) and several rare alleles. If $A_{\text {ep }}$ and $A_{\mathrm{p}}$ approximated 1 , then the profile was almost monomorphic. Enzymes involved in the primary metabolism corresponded more generally to these two types (Table 1).

On the other hand, if $A_{\text {ep }}>2$ and $A_{\mathrm{p}}>4$, then the profile comprised at least two common alleles and several rare alleles. If $A_{\mathrm{ep}}>2$ and $A_{\mathrm{p}}$ was just slightly greater than $A_{\mathrm{ep}}$, then the profile comprised only frequent alleles $(p>0.3)$. This was clearly the case for enzymes involved in the secondary metabolism. Therefore, comparison of $A_{\mathrm{p}}$ and $A_{\text {ep }}$ between the two enzyme classes showed that enzymes of class II revealed higher allelic richness $\left(A_{\mathrm{p}}=2.135\right.$ for 
enzymes of class I and $A_{\mathrm{p}}=3.420$ for enzymes of class II) but also exhibited at least two common alleles $\left(A_{\mathrm{ep}}=1.147\right.$ for enzymes of class I, and $A_{\text {ep }}=2.010$ for enzymes of class II). Frequency profiles did not vary from one population to another; the mean values indicated in Table 1 were representative of all populations.

\section{Within-population gene diversity}

Among the total number of seeds analysed (9720), 62 different alleles were identified. Gene diversity coefficients at the species level were: $A_{\mathrm{s}}=4.769$, $H_{\mathrm{es}}=0.265$ and $H_{\mathrm{os}}=0.228$. Eleven of the 13 loci were polymorphic. At the population level, because mainly expected heterozygosity depended on the most frequent alleles, frequency profiles had a clear effect on gene diversity parameters. Therefore the values of these parameters were clearly different between the two enzyme groups: all parameters $\left(A_{\mathrm{p}}\right.$, $\left.A_{\text {ep }}, H_{\text {ep }}, H_{\mathrm{op}}\right)$ showed lower values for enzymes of class I (Table 1) as already shown in a previous study (Zanetto et al., 1993). Two loci (class I) remained monomorphic.

Mean values over all loci varied among the different populations. For example, $H_{\mathrm{ep}}$ varied between 0.207 (population 74 of group 4) and 0.372 (population 23 of group 11). $A_{\mathrm{p}}$ varied between 2.385 (populations 3 and 4 of group 6) and 3.077 (popula- tion 76 of group 4). Analysis of variance between the geographical groups revealed that there were significant group differences for $A_{\mathrm{p}}$ and $H_{\mathrm{op}}$ (Table 2). These differences appeared to be geographically distributed, as shown by the significant correlations between gene diversity parameters and geographical data, based on the calculations made at the population level. All four parameters were correlated with longitude, whereas correlations with altitude were only significant for $A_{\text {ep }}$ and $H_{\text {ep }}$, and no correlations were significant with latitude (Table 2). Latitude and altitude were significantly correlated because of the geographical distribution of populations, which may

Table 2 Correlation between geographical data and parameters of gene diversity for Quercus petraea

\begin{tabular}{lrrcc}
\hline & Latitude & Longitude & Altitude & $\begin{array}{c}F \text {-test } \\
(P \text {-values })\end{array}$ \\
\hline$A_{\mathrm{p}}$ & 0.188 & $0.249^{*}$ & 0.083 & $3.03(0.001)$ \\
$A_{\mathrm{ep}}$ & 0.162 & $-0.274^{*}$ & $-0.317^{* *}$ & $0.95(0.505)$ \\
$H_{\mathrm{ep}}$ & 0.158 & $-0.273^{*}$ & $-0.325^{* *}$ & $0.94(0.519)$ \\
$H_{\mathrm{op}}$ & -0.041 & $-0.328^{*}$ & -0.176 & $1.85(0.052)$ \\
\hline
\end{tabular}

Calculations were carried out on data corresponding to the eight loci analysed over all populations. $A_{\mathrm{p}}$ : number of alleles; $A_{\mathrm{ep}}$ : effective number of alleles; $H_{\mathrm{ep}}$ : expected heterozygosity; $H_{\mathrm{op}}$ : observed heterozygosity. Statistical test of correlations: ${ }^{*} P \leqslant 0.05,{ }^{* *} P \leqslant 0.01 . F$-test corresponds to ANOVA computed over geographical groups.

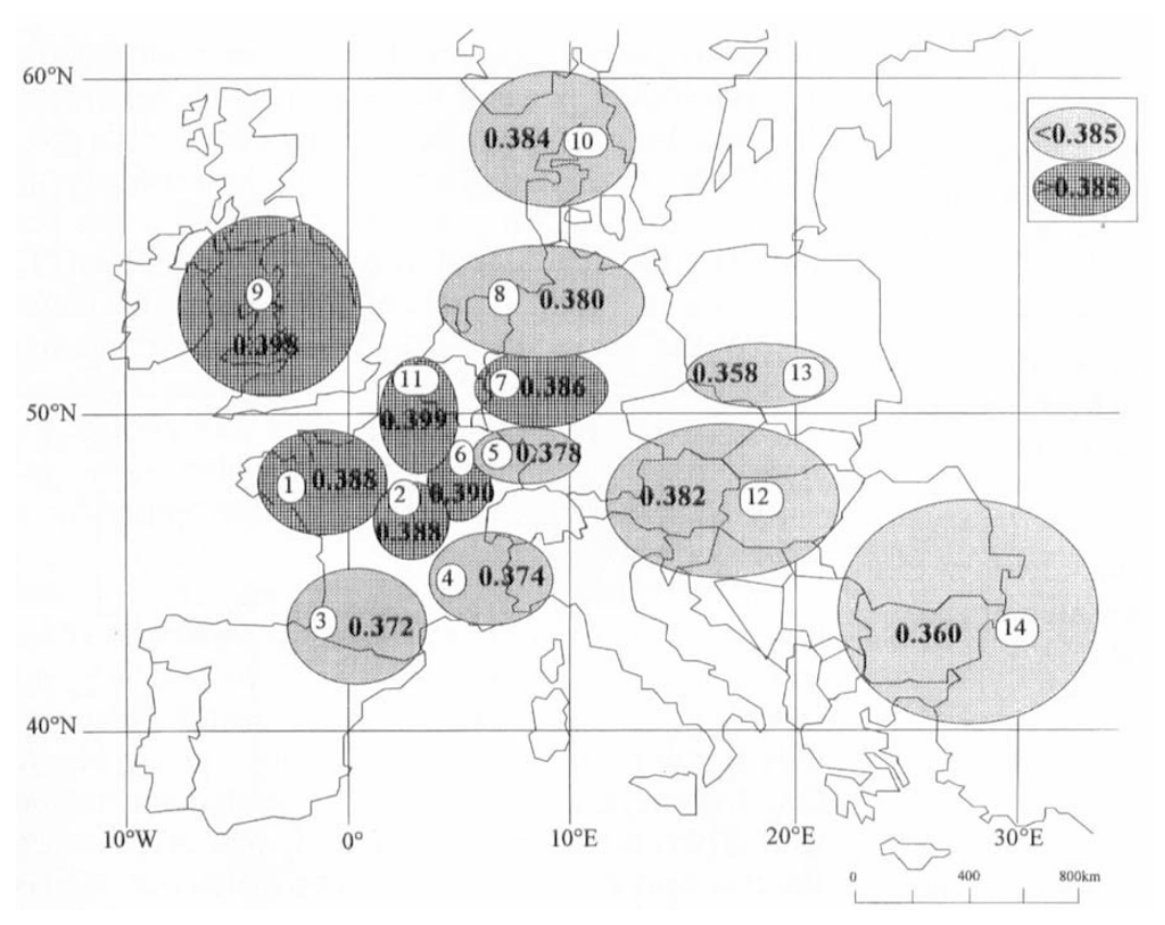

Fig. 2 Geographical distribution of mean observed heterozygosity per population of Quercus petraea. Cut-off point $(0.385)$ was chosen a priori for illustration purposes. 
explain the correlation between allele frequencies and altitude.

There were, however, opposite trends of variation for allelic richness and heterozygosity values. Populations from the Loire to the Rhine river (longitude $0-9^{\circ} \mathrm{E}$, Latitude $46-49^{\circ} \mathrm{N}$ ) had higher values of within-population heterozygosity $\left(H_{\mathrm{op}}\right)$ than populations located at the edges of the distribution (Fig. 2). Values of allelic richness $\left(A_{\mathrm{p}}\right)$ showed exactly the opposite trend of variation: populations from the edges of the distribution comprised more alleles than populations from the central part (Fig. 3). The additional alleles appeared to be rare alleles. Locus $6 P g d-B$ gives a good illustration of the pattern of variation of allelic richness. This locus was monomorphic in most populations except in those populations of group 4 (Alps), two populations of group 3 (Pyrenées) and one population of group 14. In each of these populations, more than two alleles were present.

\section{Population differentiation}

Allele frequency differences among populations were significant for all loci, although the overall population gene differentiation was low $\left(G_{\mathrm{st}}=2.5\right.$ per cent, Table 3). Genetic differentiation was lower among regional groups $\left(G_{\mathrm{gt}}=0.8\right.$ per cent) than among populations (within regional groups) $\left(G_{\mathrm{sg}}=1.7\right.$ per cent $)$. This pattern of subdivision of gene diversity was the case for all eight loci. Comparison of the differentiation coefficients between the two classes of enzymes did not show any differences between the groups, despite the different values of total diversity.

There were clear differences of differentiation within geographical groups (Table 4). The larger the area of the geographical group, the higher the level of differentiation. Populations from groups 1, 2, 6, 7 and 13 were less differentiated within their groups than populations from groups 10,12 and 14 . As a result, differentiation between populations appeared to be a function of distance and was further studied by spatial statistical methods.

Although the population differences in allele frequencies were low, they appeared to be geographically organized. Among the eight loci that were analysed over all populations, seven revealed significant correlations between allele frequencies and longitude (Table 5). Altitude and latitude were correlated with allele frequencies for only six and five loci, respectively. Correlations may be spurious for rare alleles, where numerous populations did not exhibit a single example. In most cases, however, significant correlations referred to frequent alleles. An example of the magnitude and geographical distribution of allele frequencies is shown in Fig. 4 for allele $A a p-A-4$. Although the mean frequency varied only between 0.50 and 0.70 , there was a clear longitudinal trend of variation. Western populations were
Fig. 3 Geographical distribution of mean number of alleles per population of Quercus petraea. Cut-off point (3.15) was chosen a priori for illustration purposes.

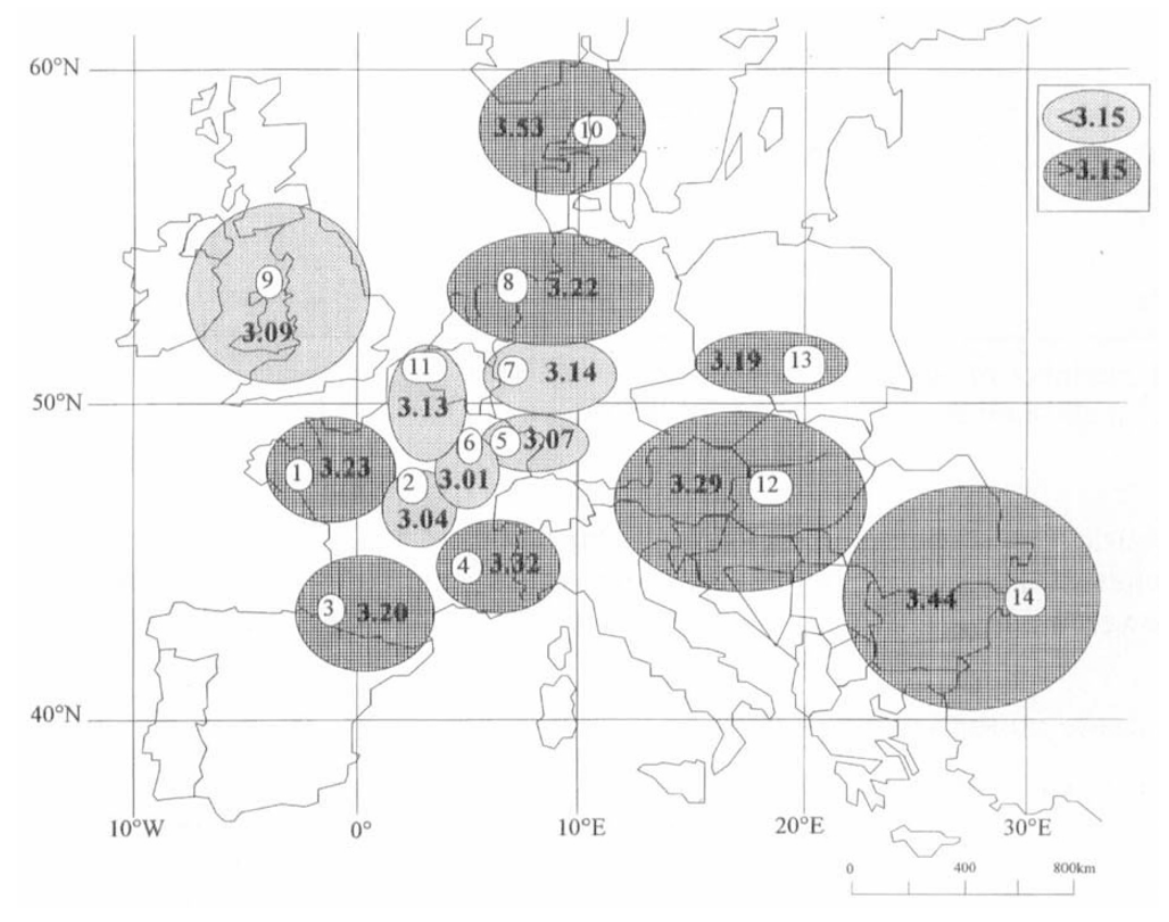


Table 3 Components of the total gene diversity for Quercus petraea

\begin{tabular}{llcccccr}
\hline Class & Locus & $H_{\mathrm{s}}$ & $H_{\mathrm{g}}$ & $H_{\mathrm{t}}$ & $G_{\mathrm{sg}}$ & $G_{\mathrm{gt}}$ & $G_{\text {st }}$ \\
\hline Enzymes of & Got $-\boldsymbol{B}$ & 0.1367 & 0.1379 & 0.1389 & 0.009 & 0.007 & 0.016 \\
class I & Pgi- $B$ & 0.3093 & 0.3128 & 0.3151 & 0.011 & 0.007 & 0.018 \\
& Pgm- $A$ & 0.1748 & 0.1785 & 0.1803 & 0.021 & 0.010 & 0.031 \\
Enzymes of & Aap $-A$ & 0.5399 & 0.5490 & 0.5542 & 0.017 & 0.009 & 0.026 \\
class II & Acp-C & 0.4947 & 0.5061 & 0.5092 & 0.022 & 0.006 & 0.028 \\
& Dia- $A$ & 0.5938 & 0.6023 & 0.6064 & 0.014 & 0.007 & 0.021 \\
& Lap- $A$ & 0.4833 & 0.4947 & 0.5014 & 0.023 & 0.013 & 0.036 \\
& Mr-A & 0.3515 & 0.3569 & 0.3593 & 0.015 & 0.007 & 0.022 \\
& Mean values & 0.3855 & 0.3923 & 0.3956 & $0.017^{1}$ & $0.008^{2}$ & $0.025^{3}$ \\
\hline
\end{tabular}

$\left.{ }^{1} G_{\mathrm{sg}}=\left(\bar{H}_{\mathrm{g}}-\bar{H}_{\mathrm{s}}\right) / \bar{H}_{\mathrm{t}}\right)$

$\left.{ }^{2} G_{\mathrm{gt}}=\left(\bar{H}_{\mathrm{t}}-\bar{H}_{\mathrm{g}}\right) / \bar{H}_{\mathrm{t}}\right\}$ where $\bar{H}_{\mathrm{g}}, \bar{H}_{\mathrm{s}}$ and $\bar{H}_{\mathrm{t}}$ are means values over all loci.

$\left.{ }^{3} G_{\mathrm{st}}=\left(\bar{H}_{\mathrm{t}}-\bar{H}_{\mathrm{s}}\right) / \bar{H}_{\mathrm{t}}\right\}$

$H_{\mathrm{s}}$ : gene diversity within populations; $H_{\mathrm{g}}$ : gene diversity within regional groups; $H_{\mathrm{t}}$ : total gene diversity; $G_{\mathrm{sg}}$ : coefficient of gene differentiation within geographical groups (among populations); $G_{\mathrm{gt}}$ : coefficient of gene differentiation among regional groups; $G_{\mathrm{st}}$ : coefficient of gene differentiation over all populations.

Table 4 Diversity and differentiation parameters within geographical groups of Quercus petraea

\begin{tabular}{lccrr}
\hline & \multicolumn{2}{c}{ Diversity within groups } & \multicolumn{2}{c}{ Differentiation within groups } \\
\cline { 2 - 3 } Groups & $A_{\mathrm{p}}$ & $H_{\mathrm{op}}$ & $G_{\text {st }}$ & $G_{\text {st }}^{\prime}$ \\
\hline 1 & 3.234 & 0.356 & 0.010 & 0.011 \\
2 & 3.045 & 0.345 & 0.006 & 0.006 \\
3 & 3.200 & 0.337 & 0.011 & 0.013 \\
4 & 3.325 & 0.345 & 0.022 & 0.028 \\
5 & 3.071 & 0.333 & 0.025 & 0.029 \\
6 & 3.018 & 0.354 & 0.009 & 0.011 \\
7 & 3.143 & 0.328 & 0.009 & 0.010 \\
8 & 3.237 & 0.338 & 0.015 & 0.016 \\
9 & 3.094 & 0.343 & 0.025 & 0.032 \\
10 & 3.531 & 0.319 & 0.041 & 0.054 \\
11 & 3.125 & 0.374 & 0.021 & 0.028 \\
12 & 3.275 & 0.347 & 0.045 & 0.056 \\
13 & 3.188 & 0.305 & 0.005 & 0.009 \\
14 & 3.438 & 0.271 & 0.033 & 0.064 \\
\hline
\end{tabular}

$A_{\mathrm{p}}$ : number of alleles; $H_{\mathrm{op}}$ : observed heterozygosity; $G_{\mathrm{st}}$ : coefficient of gene differentiation over all populations;

$G_{\text {st }}^{\prime}$ : absolute coefficient of gene differentiation.

characterized by frequencies between 0.60 and 0.70 whereas all eastern populations showed frequencies lower than 0.60 .

\section{Spatial pattern of allele frequencies}

Moran's I correlogram (Fig. 5) was characterized by: (i) strong positive autocorrelations at short distances $(<200 \mathrm{~km})$, (ii) strong negative values at large distances $(>1200 \mathrm{~km})$ and (iii) a monotonic decrease with distance between the two extremes with a peak of positive values at $1100 \mathrm{~km}$.

There was no apparent difference between enzymes of the primary and secondary metabolism. Higher genetic similarities between populations separated by less than $200 \mathrm{~km}$ have already been shown by the $G_{\text {st }}$ values within the different geographical groups. Negatives values of $I$ at the furthest geographical distances correspond to allele frequency differences between populations located 
Table 5 Correlation between allelic frequencies and geographical data for populations of Quercus petraea

\begin{tabular}{|c|c|c|c|c|}
\hline Allele & Frequency $\dagger$ & Latitude & Longitude & Altitude \\
\hline Aap-A-3 & $\mathrm{i}$ & $-0.309^{* *}$ & $-0.348^{* *}$ & 0.205 \\
\hline Aap-A-4 & f & 0.114 & $0.210^{*}$ & -0.150 \\
\hline Aap-A-5 & $\mathrm{r}$ & $0.282^{*}$ & $0.320^{* *}$ & -0.116 \\
\hline$A c p-C-1$ & $\mathrm{r}$ & $0.285^{* *}$ & 0.128 & -0.144 \\
\hline$A c p-C-2$ & f & 0.130 & $-0.285^{*}$ & $-0.342^{* *}$ \\
\hline$A c p-C-4$ & f & -0.163 & 0.212 & $0.346^{* *}$ \\
\hline$A c p-C-5$ & $r$ & -0.021 & $0.688^{* * *}$ & -0.165 \\
\hline Dia- $A-2$ & $r$ & -0.109 & -0.028 & $0.461^{* * *}$ \\
\hline Dia- $A-3$ & f & $0.309^{* *}$ & -0.124 & $-0.293^{* *}$ \\
\hline Dia- $A-4$ & f & -0.116 & $0.327^{* *}$ & 0.118 \\
\hline Dia-A-6 & $\mathrm{i}$ & $-0.238^{*}$ & $-0.259^{*}$ & 0.135 \\
\hline Lap- $A-2$ & f & $0.284^{*}$ & $0.299^{* *}$ & $-0.231^{*}$ \\
\hline Lap- $A-4$ & f & $-0.336^{* *}$ & $-0.393^{* * *}$ & 0.206 \\
\hline Lap- $A-5$ & $\mathrm{i}$ & $0.249^{*}$ & $0.420^{* * *}$ & 0.019 \\
\hline$M r-A-2$ & $\mathrm{r}$ & -0.112 & 0.055 & $0.360^{* * *}$ \\
\hline$M r-A-3$ & $\mathrm{f}$ & $0.263^{*}$ & 0.127 & $-0.240^{*}$ \\
\hline$M r-A-4$ & $\mathrm{i}$ & -0.086 & $0.391^{* * *}$ & 0.082 \\
\hline$M r-A-7$ & $\mathrm{i}$ & -0.212 & $-0.379 * * *$ & 0.041 \\
\hline Pgi-B-1 & $\mathrm{r}$ & 0.136 & $0.243^{*}$ & -0.077 \\
\hline Pgi-B-5 & f & -0.160 & $0.339^{* *}$ & $0.277^{*}$ \\
\hline Pgi-B-6 & $\mathrm{i}$ & 0.088 & $-0.346^{* *}$ & -0.156 \\
\hline$P g m-A-4$ & f & -0.029 & $0.204^{*}$ & 0.098 \\
\hline Pgm-A-5 & $\mathrm{r}$ & 0.212 & $-0.225^{*}$ & $-0.278^{*}$ \\
\hline$P g m-A-6$ & $\mathrm{r}$ & -0.040 & $0.283^{*}$ & 0.022 \\
\hline
\end{tabular}

Statistical tests of correlations: ${ }^{*} P \leqslant 0.05,{ }^{* *} P \leqslant 0.01,{ }^{* * *} P \leqslant 0.001$.

†Frequency of the allele: $\mathrm{r}=$ rare allele (allelic frequency $\leq 0.05$ ); $\mathrm{i}=$ allele with intermediate frequency $(0.05<$ allelic frequency $\leq 0.20)$; $\mathrm{f}=$ frequent allele (allelic frequency $>0.20$ ).

Fig. 4 Regional mean values of the frequency of allele Aap-A-4 of Quercus

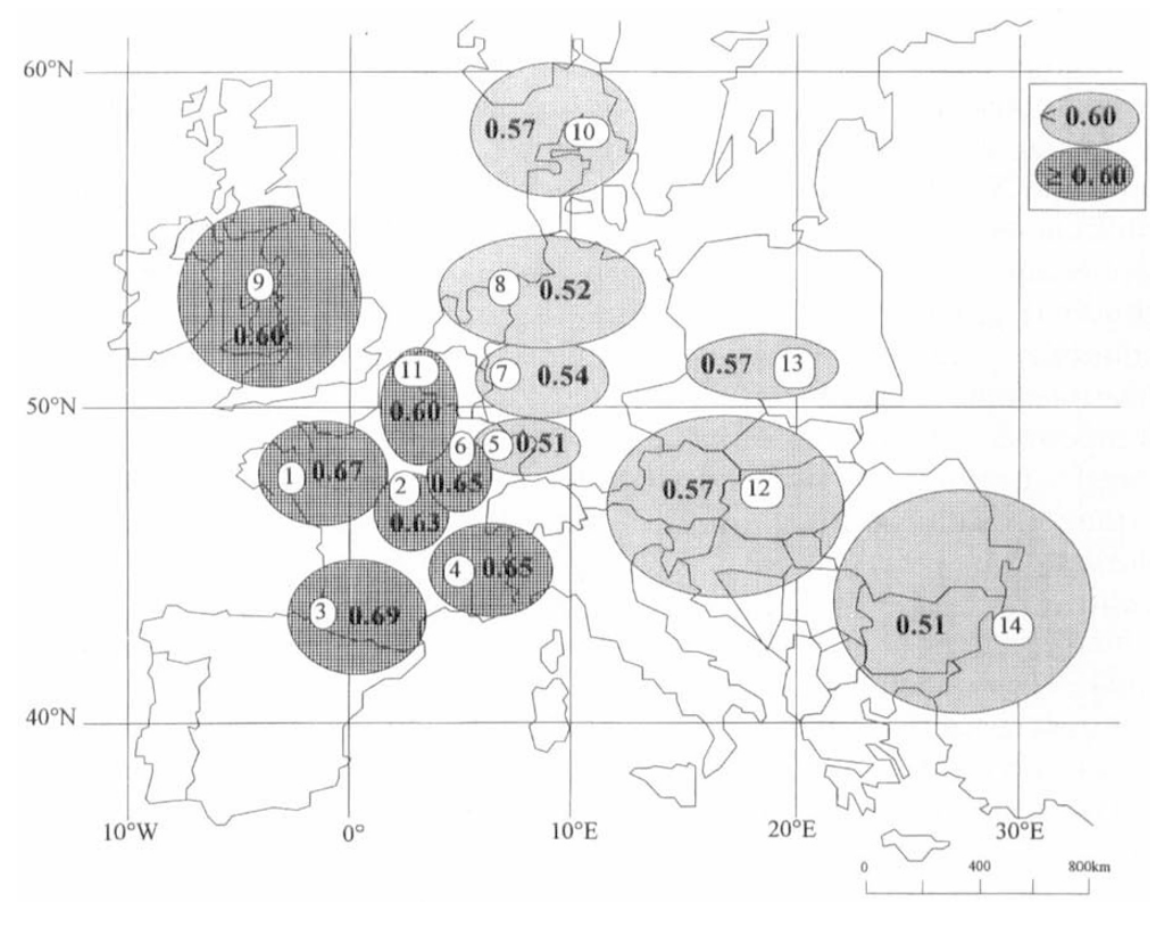
petraea. Cut-off point $(0.60)$ was chosen $a$ priori for illustration purposes. 


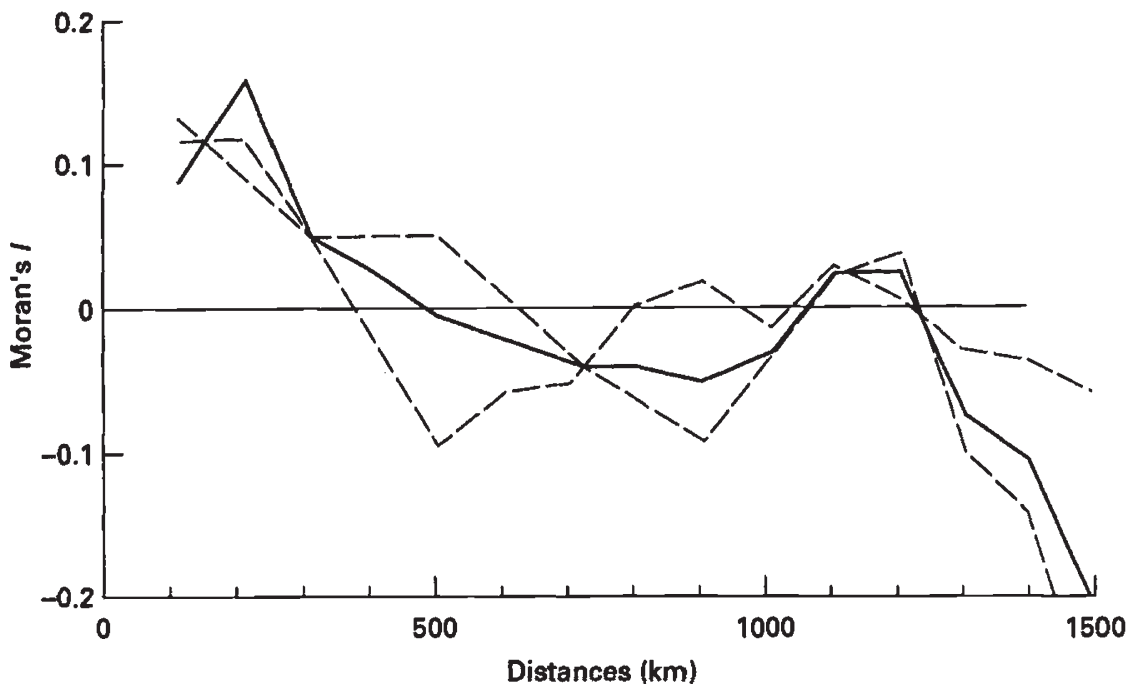

Fig. 5 Spatial autocorrelogram of allele frequencies for Quercus petraea. Mean over eight loci with the most frequent allele of each locus. Distance class interval $=100 \mathrm{~km}$. ( all loci; (--) mean of loci corresponding to enzymes of class I; ( $\rightarrow+\infty)$ mean of loci corresponding to enzymes of class II. at the extreme eastern and western edges of the distribution. The constant decrease at intermediate distances indicates continuous variation of allele frequencies. The second peak at $1100 \mathrm{~km}$ may result from similarities of allele frequencies existing between populations located at the extreme latitudes in the eastern and western part of the distribution. As shown in Fig. 4, populations from Scandinavia showed similar Aap- $A-4$ frequencies to populations from the Balkans.

\section{Discussion}

\section{Clinal variation of allele frequencies}

Although single locus gene differentiation between populations was small considering the large geographical area sampled ( $G_{\text {st }}$ varying between 1.6 per cent and 3.7 per cent), allele frequencies showed a continuous pattern of variation as shown by their significant correlations with geographical data. Longitudinal gradients appeared to be the more pronounced across loci, although significant relationships existed with altitude or latitude. Range-wide studies in other European temperate forest trees indicate similar longitudinal patterns of variation. Multivariate statistics of allele frequencies showed that spruce populations were arranged from Central Europe to the Ural mountains along a continental gradient (Lagercrantz \& Ryman, 1990). Principal components analysis based on allele frequencies of three loci revealed a longitudinal type of variation in European beech (Comps et al., 1991).

There are two evolutionary hypotheses to account for the existing clinal variation in allele frequencies. The first advocates selection of different alleles favoured along a geographical or ecological gradient (Endler, 1977). The second refers to dispersal along a geographical axis (Wijsmann \& Cavalli-Sforza, 1984). Theoretical studies show that both processes, acting solely or in combination, end in parallel variation of allele frequencies along an axis corresponding to either the ecological gradient or the migration direction (Felsenstein, 1976; Fife \& Peletier, 1981). If selection is invoked, different axes should be identified for different loci, unless these are linked. On the other hand, if concordant axes are found for all loci, then long-range gene flow probably would be responsible for clinal variation in allele frequencies (Barbujani, 1988). The results obtained for Q. petraea support the migration hypothesis, because seven out of eight loci showed concordant correlations between allele frequencies and longitude. As shown in another paper, these loci belong to different linkage groups (G. Müller-Starck et al., unpublished data). Concordant oriented patterns of gene frequencies were therefore observed for genetically independent markers, which could only be accounted for by a systematic cause, such as gene flow.

In the case of oaks, there have probably been two opposite continental migratory pathways according to the current knowledge of potential glacial refugia. Maps of fossil pollens indicate that deciduous oaks were restricted to three primary refugial areas (Huntley \& Birks, 1983, pp. 352-369): around the western side of the Bay of Biscay in northern Spain; the shores of the Black Sea on the eastern side; Italy and the Balkan peninsula in the central part. However, authors do not agree on the relative importance of these refugia. Conclusions based on the fossil pollen maps favour the western and eastern 
refugia (Huntley \& Birks, 1983, pp. 352-369) whereas combined analysis of fossil maps, past climate and physiogeography provide evidence that Italy and the western Balkans constituted a major refugium during the glacial periods (Bennett et al., 1991). The recolonization pathways probably followed two successive directions: a northern movement from all refugia, then an eastern migration for the Iberian refugium, and a western migration for the Balkan and the Black Sea refugia. These recolonization patterns may explain the existing correlation between allele frequencies and longitude (and latitude). The autocorrelogram also supports the hypothesis of widely distant refugia, as the pattern of variation corresponds to long-distance differentiation (Fig. 5). An additional consequence of the postglacial recolonization would be the existence of a transition or even a 'hybrid zone' (Hewitt, 1993) in the more central part of the distribution (present Germany). Finally, longitudinal clines have received additional support from chloroplast DNA geographical variation. Petit et al. (1993) found a longitudinal pattern of variation for four different haplotypes. Ferris et al. (1993) identified two haplotypes, one distributed in the western part of the natural range and the second in the eastern part corresponding, as the authors stated, to two separate glacial refugia. Even though inference about migration pattern from allele frequencies may be speculative (Felsenstein, 1982), chloroplast DNA data (Ferris et al., 1993; Petit et al., 1993) reinforce the view that migration pattern is the main cause of the clinal variation in allele frequencies.

\section{Geographical variation of levels of gene diversity}

The results obtained in this study show that: (i) there is a clear geographical pattern of variation in the levels of diversity as indicated by significant correlation coefficients between the gene diversity parameters and longitude; and (ii) there is an opposite trend of variation between heterozygosity $\left(H_{\mathrm{op}}\right)$ and allelic richness $\left(A_{\mathrm{p}}\right)$. More specifically, populations located between the Loire and the Rhine rivers exhibit higher levels of heterozygosity but comprise fewer alleles. The geographical variation of allelic richness might be attributed to four different processes involving either the loss of alleles in the north-western part of the range and/or the gain of alleles on the edges of the distribution. First, alleles, especially rare alleles, might have been lost because of drift during postglacial migration. In this scenario one would have expected a continuous loss along the recolonization routes, resulting in a significant decrease of alleles at the northern extremities of the natural range. The geographical distribution of allelic richness apparently does not follow this pattern (Fig. 3). Secondly, alleles might have been lost because of selection pressures. Rare alleles have been associated with decreased fitness (Bush \& Smouse, 1992). In $Q$. robur significant segregation distortions were obtained to the detriment of rare alleles (A. Zanetto et al., unpublished data). Selection against rare alleles was more likely to occur when viability selection was strongest, on optimal growing sites, where actually fewer alleles were counted (Fig. 3 ). The process advocated for the gain of alleles in the southern part of the natural range is twofold. First, more alleles might result from hybridization with other oak species. Twenty-one oak species grow in central and southern Europe whereas only two (petraea and robur) occupy the more temperate regions (Kleinschmit, 1993). Quercus petraea has four related species growing in central Europe (Czechoslovakia, Hungary, Romania) (Matyas, 1970, 1971; Stanescu, 1979; Koblizek, 1993) among which extensive hybridization has been reported (Matyas, 1967). Secondly, populations at the edges of the natural distribution might have undergone severe restrictions in their population size during their history. Recovery from bottlenecks through population expansion is followed by an increase in the frequency of the rare alleles to above equilibrium values because of new mutations (Maruyama \& Fuerst, 1985). Lagercrantz \& Ryman (1990) advocated population bottlenecks as an explanation of the excess of rare alleles in similar geographical regions (from the southern Alps to Poland) in Norway spruce. Concordant observations in two different species occupying similar geographical distributions certainly favour the bottleneck hypothesis. There is no clear evidence to support either of these evolutionary factors, or a combination of them, as a cause of the geographical pattern of allelic richness.

The opposite associated variation of observed heterozygosity might be seen as a mechanical consequence of the variation in the number of rare alleles. This antagonistic variation of two parameters of gene diversity is not a paradox if the loss of rare alleles is accompanied by an increase in the frequency of an allele with intermediate frequency, and not of the most frequent allele.

\section{Acknowledgements}

The research was supported by an ONF (Office National des Forêts) grant and by a EEC grant of 
DG12 (Programme FOREST number MA2B-CT910022) 'Description of the genetic variation in oak populations by means of molecular markers and adaptative traits.' The authors gratefully acknowledge Gregor Aas, Anna Bauer, Kornel Burg, Valeriu Enescu, Alan Fletcher, Dominique Jacques, Mustafa Kizmaz, Jochen Kleinschmit, Armin König, Hervé Le Bouler, Klaus Liepe, Sean Mac An tSaoir, Soren Madsen, Ferdinand Müller, Kórnik Pan, Tore Skrøppa, Bernd Stimm, Alexander Tucovic and the French National Forest Service (ONF) for providing the material. The authors thank Guy Roussel, Sophie Bartaire, Alexis Ducousso and Laurent Salera for their technical assistance in collecting the material and carrying out the electrophoretic analysis.

\section{References}

BACILIERI, R., DUCOUSSO, A., PETIT, R. AND KREMER, A. 1995. Mating system and directional gene flow in a mixed oak stand. Evolution (in press).

BARBUJANI, G. 1988. Detecting and comparing the direction of gene-frequency gradients. J. Genet., 67, 129-140.

BENNETT, K. D., TZEDAKIS P.C. AND WILLIS K. J. 1991. Quaternary refugia of the north European trees. J. Biogeogr., 18, 103-115.

BERGMANN, F. 1991. Isozyme gene markers. In: MüllerStarck G. and Ziehe M. (eds) Genetic Variation in European Populations of Forest Trees, pp. 67-78. J. D. Sauerländer, Frankfurt am Main.

BROWN, A. H. D. AND WEIR, B. S. 1983. Measuring genetic variability in plant populations. In: Tanksley S. D. and Orton T. J. (eds) Isozymes in Plant Genetics and Breeding, Part A, pp. 219-239. Elsevier Sciences, Amsterdam.

BUSH, R. M. AND SMOUSE, P. E. 1992. Evidence for the adaptative significance of allozymes in forest trees. New Forests, 6, 179-196.

CHELIAK, W. M., MORGAN, K., DANCIK, B. P., STROBECK, C. AND YEH, F. C. H. 1984. Segregation of allozymes in megagametophytes of viable seed from a natural population of Jack Pine, Pinus banksiana Lamb. Theor. Appl. Genet., 69, 145-151.

COMPS, B., THIÉBAuT, B. AND MERzEAU, D. 1991. Genetic variation in European beech stands. In: Müller-Starck, G. and Ziehe, M. (eds) Genetic Variation in European Populations of Forest Trees, pp. 110-124. J. D. Sauerländer, Frankfurt am Main.

CONKLE, M. T. 1992. Genetic diversity- seeing the forest through the trees. New Forests, 6, 5-22.

CONKLE, M. T., HODGKISS, P. D., NUNNALLY, L. AND HUNTER, S. 1982. Starch gel elecrophoresis of conifer seeds: a laboratory manual. United States Department of Agriculture Experiment Station. General technical report PSW 64.

ENDLER, J. A. 1977. Geographic Variation, Speciation, and Clines. Princeton University Press, Princeton, NJ.
FELSENSTEIN, J. 1982. How can we infer geography and history from gene frequencies? J. Theor. Biol., 96, 9-20.

FELSENSTEIN, J. 1976. The theoretical population genetics of variable selection and migration. Ann. Rev. Genet., 10, 253-280.

FERRIS, C., OLIVER, R. P., DAVY, A. J. AND HEWITT, G. M. 1993. Native oak chloroplasts reveal an ancient divide across Europe. Mol. Ecol., 2, 337-344.

FIFE, P. C. AND PEletier, L. A. 1981. Clines induced by variable selection and migration. Proc. $R$. Soc. Lond. B, 214, 99-123.

HAMRICK, J. L., GODT, J. W. AND SHERMAN-BROYLES, S. L. 1992. Factors influencing levels of genetic diversity in woody plant species. New Forests, 6, 95-124.

HEwITT, G. M. 1993. Postglacial distribution and species substructure: lessons from pollen, insects and hybrid zones. In: Leeds, D. R. and Edwards, D. (eds) Evolutionary Patterns and Processes, pp. 97-103. The Linnean Society of London/Academic Press, London.

huntLey, B. AND BIRKs, H. J. B. 1983. An Atlas of Past and Present Pollen Maps for Europe, 0-13,000 Years Ago. Cambridge University Press, Cambridge.

KLEINSCHMIT, J. 1993. Intraspecific variation of growth and adaptive traits in European oak species. Ann. Sci. For., 50, 166s-185s.

KoblizeK, J. 1993. Distribution of oak species in the Czech Republic. Ann. Sci. For., 50, 290s-293s.

KREMER, A. 1994. Diversité génétique et variabilité des caractères phénotypiques chez les arbres forestiers. Génét. Sél. Evol., 26, 105s-123s.

KREMER A. AND PETIT, R. J. 1993. Gene diversity in natural populations of oak species. Ann. Sci. For., 50, 186s202s.

KREMER, A., PETIT, R. J., ZANETTO, A., FOUGÈre, V., DUCOUSSO, A., WAgner, D. AND CHAUVIN, C. 1991. Nuclear and organelle gene diversity in Quercus robur and $Q$. petraea. In: Müller-Starck, G. and Ziehe, M. (eds) Genetic Variation in European Populations of Forest Trees, pp. 141-166. J. D. Sauerländer, Frankfurt am Main.

KREMER, A., SAVILL, P. S. AND STEINER, K. C. 1993. Genetics of oaks. Ann. Sci. For., 50 (suppl. 1), pp. 469.

LAGERCRANTZ, U. AND RYMAN, N. 1990. Genetic structure of Norway spruce (Picea abies): concordance of morphological and allozymic variation. Evolution, 44, 38-53.

MARUYAma, T. AND FUerst, P. A. 1985, Population bottlenecks and nonequilibrium models in population genetics. II. Number of alleles in a small population that was formed by a recent bottleneck. Genetics, 111, 675-689.

matyas, v. 1967. A Tögyek. Akadémiai Kiado Publishers, Budapest.

Matyas, v. 1970. Einführung in die Kenntnis der Eichenarten Ungarns. Erdészeti Kutatàsok, Budapest, 66, 61-68.

MATYAS, v. 1971. Short taxonomic review of the oaks of Hungary. Erdészeti Kutatàsok, Budapest, 67, 55-68.

MÜLLER-STARCK, G., HERZOG, S. AND HATTEMER, H. H. 1993. Intra- and interpopulation genetic variation in

(C) The Genetical Society of Great Britain, Heredity, 75, 506-517. 
juvenile populations of Quercus robur L. and Quercus petraea Liebl. Ann. Sci. For. 50, 233s-244s.

MÜLLER-STARCK, G. AND ZIEHE, M. 1991. Genetic variation in populations of Fagus sylvatica L., Quercus robur L., and Q. petraea Liebl. in Germany. In: Müller-Starck, G. and Ziehe, M. (eds) Genetic Variation in European Populations of Forest Trees, pp. 125-140. J. D. Sauerländer, Frankfurt am Main.

NEI, M. 1973. Analysis of gene diversity in subdivided populations. Proc. Natl. Acad. Sci. U.S.A., 12, 3321-3323.

NEI, M. 1977. F-statistics and analysis of gene diversity in subdivided populations. Ann. hum. Genet., 41, 225-233.

NEI, M. AND CHESSER, R. K. 1983. Estimation of fixation indices and gene diversities. Ann. hum. Genet., 47, 253-259.

PETTT, R. J., KREMER, A. AND WAGNER, D. B. 1993. Geographic structure of chloroplast DNA polymorphisms in European oaks. Theor. Appl. Genet., 87, 122-128.

SOKAL, R. R., HARDING, R. M. AND ODEN, N. L. 1989. Spatial patterns of human gene frequencies in Europe. Am. J. Phys. Anthropol., 80, 267-294.

SOKAL, R. R. AND ROHLF, F. J. 1981. Biometry, 2nd edn. W. H. Freeman, San Francisco.
STANESCU, v. 1979. Genul Quercus L. In: Stejarii in Dendrologie, pp. 190-235. Editura Didacticà si Pedagogicà, Bucaresti.

STRAUSS, S. H., BOUSQUET, J., HIPKINS, V. D. AND HONG, Y.p. 1992. Biochemical and molecular genetic markers in biosystematic studies of forest trees. New Forests, 6, $125-158$.

VALLEJOS, C. E. 1983. Enzyme activity staining. In: Tanksley, S. D. and Orton, T. J. (eds) Isozymes in Plant Genetics and Breeding, Part A, pp. 469-515. Elsevier Sciences, Amsterdam.

WIJSMANN, E. M. AND CAVALll-SFORZA, L. L. 1984. Migration and genetic population structure with special reference to humans. Ann. Rev. Ecol. Syst., 15, 279-301.

WRIGHT, J. W. 1976. Introduction to Forest Genetics. Academic Press, New York.

ZANETTO, A., KREMER, A. AND LABBÉ, T. 1993. Differences of genetic variation based on isozymes of primary and secondary metabolism in Quercus petraea. Ann. Sci. For., 50, 245s-252s.

ZANETTO, A., ROUSSEL, G. AND KREMER, A. 1994. Geographic variation of inter-specific differentiation between Quercus robur L. and Quercus petraea (Matt.) Liebl. Forest Genet., 1, 111-123. 